\title{
The New Third Rome: Readings of a Russian Nationalist Myth
}

\section{Ulrich Schmid}

To cite this article: Ulrich Schmid (2017): The New Third Rome: Readings of a Russian Nationalist Myth, Scando-Slavica

To link to this article: http://dx.doi.org/10.1080/00806765.2017.1389890

册 Published online: 10 Nov 2017.

Submit your article to this journal $\widetilde{ }$

Q View related articles $\longleftarrow$

View Crossmark data \lceil 


\section{BOOK REVIEW}

The New Third Rome: Readings of a Russian Nationalist Myth, by Jardar Østbø, with a foreword by Pål Kolstø, Stuttgart: ibidem, 2016, 258 pp. (Soviet and Post-Soviet Politics and Society 151), ISBN: 9783838209005 (pbk), 9783838268705 (e-book).

Famously, the myth of Moscow as the Third Rome was allegedly forged by the Pskovian monk Filofej in a letter to tsar Vasilij III in 1511. The most often quoted sentence of this letter reads: "Two Romes have fallen, one stands, a fourth there shall not be [...]." In 2011, Jardar Østbø defended his Ph.D. dissertation on contemporary elaborations about the myth of the Third Rome at the University of Bergen. Now, the Norwegian scholar presents an updated version of his valuable and important dissertation. At the core of his book lie four case studies in which he examines the Third Rome myth as advanced by Vadim Cymburskij (1957-2009), Aleksandr Dugin (born 1962), Natalija Naročnickaja (born 1948) and Egor Cholmogorov (born 1975). Østbø describes these four authors in view of their conceptualization regarding the relation between Orthodox religion and the Russian territory. He organizes his systemic approach in the following table:

$\begin{array}{llll} & & \text { Territory } & \\ \text { Religion } & \text { Core-oriented } & \text { Imperialist } \\ & \text { Less Orthodox } & \text { Cymburskij } & \text { Dugin } \\ & \text { More Orthodox } & \text { Naročnickaja } & \text { Cholmogorov }\end{array}$

Østbø opens his book by methodological deliberations and defines key concepts such as "nationalism," "nation," "imperialism," and "political myth." He is inclined to accept a multifaceted constructivist definition of a Russian nation that encompasses both civic and cultural aspects. Russia exists on the one hand as a power structure in the organization of the state, and, on the other hand, as a cultural entity in the ideological traditions of its self legitimation.

A historical chapter deals with the history of the publication and subsequent receptions of texts that were swiftly attributed to Filofej. The journal Pravoslavnyj sobesednik first published these documents in the 1860s. However, recent scholarship demonstrated that only one of the three texts published between 1524 and 1540 may be attributed to Filofej. Moreover, the famous letter to tsar Vasilij is not among them.

In a short "tour d'horizon" Østbø describes existing idiosyncratic uses about the idea of Moscow as the Third Rome. Vladimir Solov'ev inscribed the myth of the Third Rome into his own conception of a necessary reconciliation of the Western and Eastern Christian churches. Nikolai Fedorov believed that Russia's messianistic mission as a representative of the Third Rome was to unite all human mankind. Sergej Bulgakov believed that Moscow, in its role as the Third Rome, should aspire to establish a theocracy in Russia. lurij Potechin - one of the exponents of the "Changings signposts" movement - transformed the myth of the Third Rome into the cultural imperative of the Third International, and 
called for Russia's unification by reconciling Reds and Whites. Georgij Florovskij interpreted the myth of the Third Rome as a sign of the growing rivalry between Byzantine and Muscovite orthodoxy. Nikolaj Berdjaev explained the Russian, and later Soviet expansionism, with the messianic idea of the Third Rome. In 1948, Arnold Toynbee maintained the topos of the Third Rome was nothing but a sacralizing legitimation for Russian imperialism - be it orchestrated by the Tsarist or the Soviet empire. The émigré historian Nikolaj Ul'janov criticized in his 1956 article "The Filofej complex" that Stalin's imperialist policies constituted an abuse of Filofej's original idea of a clearly delineated Russian national state. Richard Pipes saw the myth of the Third Rome as a political legend that compensated for the backward mindset of the Muscovite aristocracy.

Against the backdrop of this overview, Østbø turns to his four main protagonists. In his first case study, he deals with Vadim Cymburskij (1957-2009), a geopolitical philosopher who came up with an isolationist conception for Russia's future. Cymburskij was close to the political engineers Gleb Pavlovskij and Stanislav Belkovskij. Pavlovskij paid for Cymburskij's cancer treatment during the last years of his life, and Belkovskij arranged for the publication of his works on geopolitics in 2007. After his untimely death, Cymburskij became a cult figure among conservative intellectuals. Cymburskij employs a "cultural-geographical method" and distinguishes Germano-Romanic Western Christianity from Slavonic Eastern Christianity. Eastern and Western civilizations are not divided by a distinct border, but connected by a belt of cultures, which he calls "limitroph." Cases in point are the Slavonic yet Catholic Poles, or the Romance yet Orthodox Romanians. This analysis leads Cymburskij to his famous metaphorical concept of the "island Russia." The "geopolitical object" Russia should isolate itself from pernicious Western influences and safeguard its own unique civilization.

Østbø's second case study deals with Aleksandr Dugin, one of the most prolific right-wing intellectuals in Russia. Østbø discusses the ties between the Kremlin and Dugin often, but the extent of his influence on the inner circle of power is questionable. Dugin started off as a National-Bolshevik. After his falling out with Eduard Limonov, he founded a Eurasian movement that is still active today. Dugin's ideology is highly eclectic; He perceives Russia as the true scion of the Roman Empire, in opposition to the West, and especially the United States, whom he perceives as descendants of Carthago. In his view, Russia is a tellurian civilization with an emphasis on community, tradition, and heroism whereas the West stresses the importance of the individual, modernity and trade. Dugin even issues an absolute imperative for the warriors of the Russian empire. They are entitled to kill in order to defend and to safeguard their own position. Dugin detects evil influences of Western culture as early as the $17^{\text {th }}$ century. The church reforms of patriarch Nikon of 1666 that lead to a split in the Russian Orthodox Church are still apparent today. Dugin himself is a practicing Old believer. Every attempt at a Western modernization of Russia is seen as a threat. Consequently, Dugin presents Peter the Great as an enemy of the Russian civilization. "Russia" becomes a metaphysical category that stands above all other entities. In a discussion of Dostoevskij's Crime and Punishment, Dugin even 
maintains the Russian "Crime is incommensurably higher than the virtue of others."

After Dugin, Østbø turns to a major figure of the political and academic establishment in Putin's Russia. Natalija Naročnickaja is a historian with patriotic views. She published a book on Russia and Russians in World History in 2009. She considers Russia the true guardian of Christian values since the West turned to capitalistic and individualistic ideologies. She also criticizes what she calls the Western myth of an alleged "Filofeism" - a false doctrine of an alleged imperialistic drive of Russia. Østbø argues convincingly that Naročnickaja inverted the traditional myth of the Third Rome, and denounces it as an instrument used by Western antiRussian propaganda. Østbø as an astute reader of Naročnickaja even detects a piece of plagiarism in her opus magnum where she borrows almost literally from Nikolaj UI'janov's essay on the Filofej complex.

In the next chapter, Østbø studies the position of Egor Cholmogorov, an extremely conservative journalist who appears to be a self taught cultural historian. Cholmogorov claims Russia may exist only in the form of an empire. Its expansion shall be guaranteed by two means: religion and the atomic bomb. Cholmogorov sees "nuclear orthodoxy" and "hagiopolitics" as the basis for the organization of power in Russia. Moreover, he has a distinctly Hegelian view of political power. He does not argue for democratic representation or authoritarian administration, but emphasizes what he calls "sensocracy" (smyslokratija). Cholmogorov wants to regulate not political discourse in itself, but the ramifications of this discourse. This is a clear departure from exerting political power via the mass media: "Mediocracy manipulates the ways to speak, but sensocracy manipulates the very possibility to speak." Consequently, Cholmogorov has a very positive view of Vladislav Surkov who appears to be one of the best managers of "sensocracy" in the Putin era.

$\emptyset$ stbø concludes his book with a chapter on current developments. He pays special attention to the use of the myth of the Third Rome in the context of the Ukrainian crisis. It is obvious that Naročnickaja, Dugin and Cholmogorov all fervently welcomed the "reunification" of Crimea with Russia. However, unlike Dugin and Cholmogorov, Naročnickaja kept a low profile when it came to the events in the Donbas. Dugin and Cholmogorov openly criticized the Kremlin for not backing the separatists sufficiently, whereas Naročnickaja never dared to challenge the official line of policy.

Naročnickaja and Dugin repeated their interpretations of the myth of a Third Rome in the context of the extravagant exhibition "My History" in Moscow's Manege Hall. They participated in a conference entitled "Moscow the Third Rome" that was organized by the influential Archimandrite Tichon Ševkunov and the orthodox oligarch Konstantin Malofeev. Tichon is very close to the Russian president, and Malofeev runs a religious TV Channel with the programmatic name "Car'grad." On this occasion, Dugin went as far as to call for an inscription of the Third Rome myth into the UNESCO world heritage.

Østbø's study on the myth of the Third Rome is an important book with many insights into the creation of a new ideology for Russia at the beginning of the $21^{\text {st }}$ century. The main strength of Østbø's book lies in the meticulous analysis of the uses the four selected authors made of the myth of the Third Rome. More could 
have been said about the institutional networks into which the four authors feed their conservative views. In the biographical sketches, Østbø mentions the public offices and academic allegiances of his authors, but fails to give an assessment of their respective audiences and their political impact. The sociology of the new Russian conservative thought remains a topic for research. Notwithstanding these criticisms, Østbø has made a very innovative and insightful contribution to the study of the intellectual legitimation of the authoritarian Russian state in the Putin era.

Ulrich Schmid School of Humanities and Social Sciences, University of St. Gallen,

St. Gallen, Switzerland Qulrich.schmid@unisg.ch

(c) 2017 Ulrich Schmid https://doi.org/10.1080/00806765.2017.1389890

Check for updates 